\title{
Assessment of Tomato (Solanum lycopersicum L.) Producers' Exposure Level to Pesticides, in Kouka and Toussiana (Burkina Faso)
}

\author{
Diakalia Son ${ }^{1,2, *} \mathbb{1}$, Fabrice K. B. Zerbo ${ }^{1}$, Schémaeza Bonzi ${ }^{1}$, Anne Legreve ${ }^{3}$, Irénée Somda ${ }^{1}$ \\ and Bruno Schiffers ${ }^{2}$ \\ 1 Agrosystèmes et Ingénierie de l’Environnement (Sy.N.A.I.E), Unité Santé des Plantes du Laboratoire \\ Systèmes Naturels, Institut du Développement Rural (IDR), Université Nazi Boni (UNB), \\ 01 BP 1091 Bobo-Dioulasso, Burkina Faso; benzerbo@yahoo.fr (F.K.B.Z.); ouakobonzi@yahoo.fr (S.B.); \\ ireneesomda@yahoo.fr (I.S.) \\ 2 Gembloux Agro-Bio Tech/ULIEGE-Pesticide Science Laboratory, Passage des Déportés 2, 5030 Gembloux, \\ Belgium; bruno.schiffers@ulg.ac.be \\ 3 Phytopathology, Earth and Life Institute, Catholic University of Louvain, Croix du Sud, \\ 2 bte L7.05.03, B-1348-Louvain-la-Neuve, Belgium; anne.legreve@uclouvain.be \\ * Correspondence: sondiakalia@yahoo.fr; Tel.: +226-76-44-77-53 (Burkina Faso); +32-465-22-94-38 (Belgium)
}

Received: 29 December 2017; Accepted: 23 January 2018; Published: 25 January 2018

\begin{abstract}
To assess producers' exposure level to pesticides in vegetable production in Burkina Faso, a study was carried out in 2016 and 2017 among 30 tomato producers in the municipalities of Kouka and Toussiana. Eighteen (18) commercial formulations were identified, with more than $50 \%$ of pesticides destined for cotton production. Eleven active substances have been identified and the most frequently used are $\lambda$-cyhalothrin (35\%), acetamiprid (22\%) and profenofos (13\%). The most commonly used chemical families are pyrethroids $(28 \%)$ and organophosphates $(18 \%)$. The study revealed a low level of training for producers, a high use of pesticides according to the Frequency Treatment Indicator, and a very low level of protection used by producers. The Health Risk Index shows that active substances such as methomyl, $\lambda$-cyhalothrin and profenofos present very high risk to operators' health. Based on the UK-POEM model, the predictive exposure levels obtained varied from $0.0105 \mathrm{mg} / \mathrm{kg}$ body weight/day to $1.7855 \mathrm{mg} / \mathrm{kg}$ body weight/day, which is several times higher than the Acceptable Operator Exposure Level. However, the study also shows that exposure can be greatly reduced if the required Personal Protective Equipment is worn. Producers' awareness and training on integrated pest management are necessary to reduce the risks linked to the pesticides use in Burkina Faso.
\end{abstract}

Keywords: tomatoes; pesticides; risk assessment; UK-POEM; producers; Burkina Faso

\section{Introduction}

In Burkina Faso, tomato cultivation only takes second place to onions with a production of 289,572 tons on an area of 11,766.4 ha during the 2013-2014 vegetable season [1]. However, this production is subject to many constraints, including pest pressure (Bemisia tabaci Gennadius, Helicoverpa armigera Hübner, Tuta absoluta Meyrick), which forces producers to intensify chemical treatments beyond suggested recommendations by overdosing or increasing the number of treatments [2-4]. Although plant protection products (PPP) enable satisfactory results in agricultural production, their use is risky to human health, the environment and non-target organisms [5-7]. This risk is higher because of the use in vegetable production of toxic and highly concentrated PPPs intended to combat pests in cotton without appropriate protective equipment $[8,9]$. Surveys on phytosanitary practices in tomato production in Burkina Faso show that more than $70 \%$ of producers 
do not take adequate protective measures during PPP use [9]. Several studies have shown that skin exposure remains the main risk allowing pesticide penetration into the human body $[7,10]$. This could explain the adverse effects experienced by producers (skin irritations, hot flushes, headaches, etc.) following pesticide application [11-13]. $72 \%$ of 316 producers, surveyed on their phytosanitary practices in tomato production in Burkina Faso, complained of acute poisoning during or after pesticide application [9]. In addition to these acute effects, the chronic effects of pesticides on producers' health, such as cancer, neurological diseases and reproductive disorders, have been highlighted by several authors $[7,14]$. On top of all this, a misuse of PPPs can also lead to consumer exposure (residues in food and water), environmental contamination (water and soil), emergence of resistant strains and auxiliary fauna destruction $[15,16]$.

Compared to cotton production, few studies have evaluated the potential exposure of Burkina Faso vegetables producers' to pesticides $[7,11]$. However, the significant development of vegetables gardening in Burkina Faso and the intensification of phytosanitary treatments, especially in tomato production, which have not been preceded by any impact study beforehand, justify this study considering that measuring the risk to operators is an obligation when registering PPPs $[17,18]$.

It is in this context that this field study marked by close monitoring of some tomato producers surveyed in 2015-2016 [9], was carried out in 2016 and 2017, not only to further characterize their practices, assess the frequency and intensity of phytosanitary treatments, but also to assess the potential exposure of producers to these pesticides.

The importance of this paper after that on pytosanitary practices of tomato producers in Burkina Faso [9], is intended to once more draw the attention of producers and authorities to the risks associated in pesticides use and the necessity to apply the better phytosanitary practices.

\section{Materials and Methods}

\subsection{Observation Sites}

In order to characterize producers' phytosanitary practices, surveys and close monitoring were made in the provinces of Banwa in 2016 and Houet in 2017 (Western Burkina Faso). In each province, 15 tomato producers were randomly selected from the six main production sites located in two communes (Kouka and Toussiana) (Figure 1).

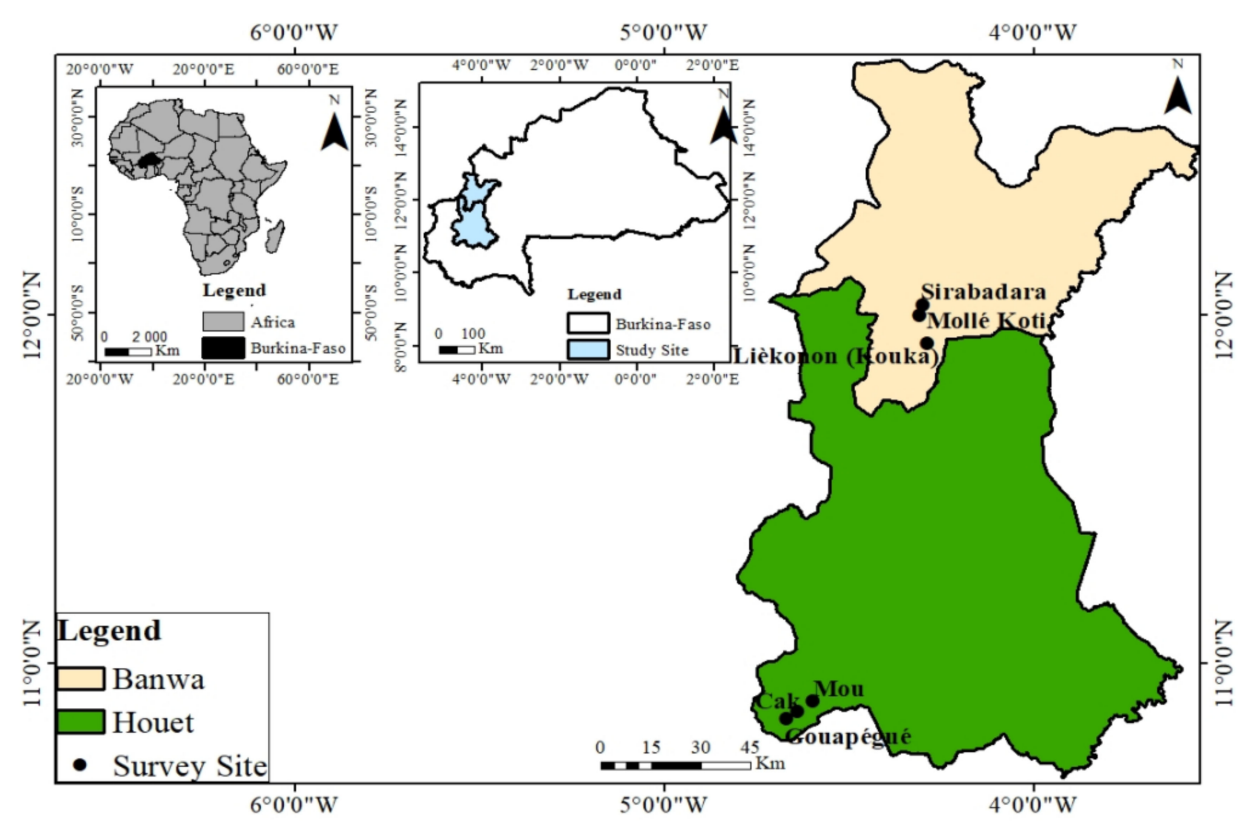

Figure 1. Location of the six observation sites of phytosanitary practices of tomato producers in the communes of Kouka and Toussiana (Burkina Faso). 
These volunteer producers were selected from those surveyed in 2015-2016 on their phytosanitary practices [9] to follow end-to-end their phytosanitary practices (pesticides used, dosage, Personal Protective Equipment (PPE) worn during treatments, etc.) since the transplanting of their tomato plants until the harvest, by systematically recorded all activities and behaviors during pesticides use.

\subsection{Observations and Measurements}

In order to assess producer's dependency and exposure to pesticides, observations and measurements were made on 30 producers during phytosanitary applications. Those observations were based on:

- The pesticides used by the producer (commercial name of the PPP, active substances, recommended dose and actual dose used);

- $\quad$ The personal protective equipment (PPE) worn by the producer;

- The quality of the material (measuring container used for dosing and spraying);

- The negligent behaviour (eating, smoking, urinating, ...) during the application;

- $\quad$ The sanitation measures taken after pesticide application immediately washing hands and feet.

The measures related to the PPP application conditions are:

- $\quad$ The treated area during each application, using a Global Positioning System (GPS);

- $\quad$ The doses and volumes of spray mix used, with graduated receptacles;

- Preparation, application and rinsing times of the equipment, using a chronometer;

- Temperature $\left({ }^{\circ} \mathrm{C}\right)$ and wind speed $(\mathrm{m} / \mathrm{s})$, using a CFM/CMM Thermo-Anemometer, model DT-619 (Ruby Electronics, Saratoga, CA, USA);

- $\quad$ Air humidity, with a digital thermo-hygrometer using a Profi-Thermo-Hygrometer, TFA (Dostmann $\mathrm{GmbH}+\mathrm{Co} . \mathrm{KG}$, Zum Ottersberg, Germany).

\subsection{Computation of the Health Risk Indexes}

Based on the information collected on the phytosanitary practices of producers and data indexed in databases on the pesticides' toxicological properties (SAgE pesticides), the health risk indexe (HRI) was calculated using the Quebec-IRPeQ pesticides risk indicator developed by the Quebec National Institute of Public Health (INSPQ), the Quebec Ministry for Sustainable Development, the Environment and the Parks (MDDEP) and the Quebec Ministry for Agriculture, Fisheries and Food (MAPAQ) [19]. The toxicological data used to compute the indexes have been collected in various databases [European Union Pesticide Database, SAgE Pesticides (Canada), Agritox and INERIS (France), etc.]. These toxicological properties have been classified according to their Classification, Labeling and Packaging (CLP) by the EU-Pesticides Database [20]. The choice of the indicator of risks of the pesticides (IRPeQ) to calculate HRI was made by considering the availability of the tool, its ease of use depending on data accessibility for the most active ingredients. It was used by [21] and by [22] in Benin and Tunisia, enabled the evaluation and toxicity comparison of various active substances. HRI calculation integrates acute toxicity values (oral $\mathrm{LD}_{50}$, dermal $\mathrm{LD}_{50}$, inhalation $\mathrm{LC}_{50}$, eyes and skin irritation, sensitization), chronic toxicity values (carcinogenic risks, reproductive and developmental risks, genotoxicity and potential endocrine disruption) modulated by a factor related with persistence and bio-accumulation of active substances in the human body (biocentration factor or BCF). It also takes into account the concentration, the formulation type and the application dose. HRI help to rank the toxicity of pesticide in order to choose those that are less harmful to human health [19]. It is calculated as follows:

$$
\begin{gathered}
H R I=\frac{T R I \times F P f \times F C P}{10} \\
H R I_{P P P}=\sum H R I_{\text {Active substance }}
\end{gathered}
$$


with:

- $\quad H R I_{\text {active substance }}=$ Health risk index for the active substance;

- $\quad T R I=$ Toxicological risk index of the active substance $=[\Sigma$ of acute toxicity points $+(\Sigma$ of chronic toxicity points $\times F P e r)]^{2}$. To obtain a greater distribution of values and to highlight more the pesticides presenting at higher risk, the sum of the variables was squared;

- $\quad F P e r=$ Factor taking into account the environmental persistence, (based on $\mathrm{TD}_{50}$ in soil) or the bioaccumulation potential in humans ( $B C F$ value). It varies from 1 to 2.5;

- $\quad F P f=$ Weighting factor related to formulation type. It varies from 1 to 2 depending on the potential contamination via the formulation (respectively low risk and high risk);

- $\quad F C P=$ Compensation factor to account for the active substance concentration in the end-use product and the applied dose (concentration $\times$ recommended dose $/ \mathrm{ha}$ );

- $\quad 10=$ Quotient to obtain an HRI of an acceptable order of magnitude, as the value obtained may be very high for some active substances with high TRI.

The criteria for acute and chronic toxicity of the active substances are weighted by points [19].

\subsection{Treatments Frequency and Intensity Indicator}

The treatment frequency index (TFI) corresponds to the ratio between the applied dose and the dose recommended on the label, taking into account the area of the treated plot [23,24]. Each application is regarded as a treatment, even in the case where the product is used in divided doses. A mixture of two products applied during the same passage also counts for two treatments:

$$
T F I_{\text {Treatment }}=\frac{D U \times S t}{R D \times S T}
$$

with:

- $\quad T F I_{\text {Treatment }}=$ TFI calculated during each PPP application;

- $\quad D U=$ Dose used by the producer during each loading of the sprayer;

- $\quad R D=$ Recommended dose of the PPP;

- $\quad S t=$ Area of the plot treated during each application;

- $\quad S T=$ Total field area.

The TFI per plot corresponds to the sum of TFIs per treatment throughout the production cycle:

$$
T F I_{\text {Plot }}=\sum T F I_{\text {treatment }}
$$

The calculated TFI is compared to the regional or national reference TFI. In case of absence of a reference TFI, it is compared with the 70th percentile of the TFI for the crop considered after surveying a minimum of 30 plots [25].

\subsection{The Model Used to Assess Producers Dermal Exposure}

In order to estimate the potential exposure level (PE, in $\mathrm{mg} / \mathrm{kg}$ body weight/day), the British model or the UK Predictive Operator Exposure Model (UK-POEM) was used. It is presented on an Excel sheet (Figure 2). Parameters such as the application method, the formulation and the PPP' concentration, the personal protective equipment (PPE), the dose and the volume of application were used in the model in accordance with local practice. This model was also used by other authors [7,26,27]. All the required parameters in this model are presented in the Table 1.

The total predictive exposure is the sum of dermal and inhalation exposure during mix/loading (mainly through hands contact) and the spraying (droplets received all over the body). The predictive exposure was estimated for two scenarios: without PPE, to the most common scenario in Burkina 
Faso, and with PPE (mask, gloves and coverall). The calculation is made by active substance and for each pesticide.

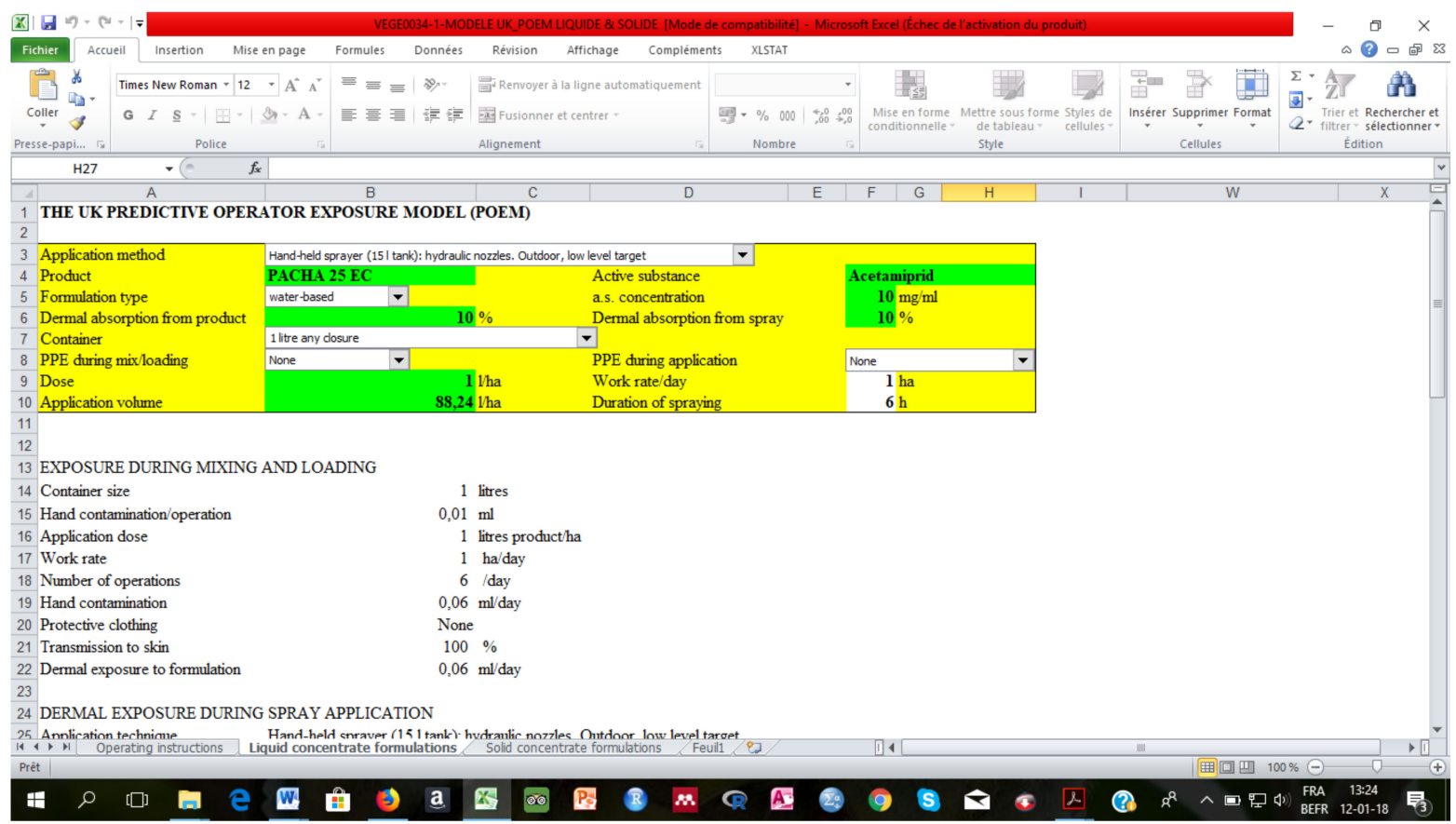

Figure 2. Screenshot of the UK-POEM model spreadsheet.

Table 1. Parameters used in the UK-POEM model to estimate producers' potential exposure to pesticides.

\begin{tabular}{cc}
\hline Parameters Used in the UK-POEM Model & Details \\
\hline Application method & Backpack sprayer (15 L tank) \\
Formulation type & EC, SC or WP \\
Dermal absorption from product & $10 \%$ default value [28] \\
Absorption through inhalation & $100 \%$ default value [28] \\
Container & $1 \mathrm{~L}$, any closure \\
Personal Protective Equipment (PPE) & Scenario 1: none \\
Surface treated/day & Scenario 2: mask, gloves and coverall \\
Duration of spraying & 1 ha (default value) \\
Operator weight & 6 h (default value) \\
\end{tabular}

\subsection{Risk Characterization}

The risk for each active substance used by the producers was characterized by comparing the predictive exposure value expressed in $\mathrm{mg} / \mathrm{kg}$ body weight/day with Acceptable Operator Exposure Level (AOEL). When this value is lower than the value of AOEL, the risk may be considered acceptable. If the risk is considered unacceptable for the market gardener, mitigation measures should be recommended.

\subsection{Statistical Analysis}

The treatment frequency index (TFI) values of the different sites, after a logarithmic transformation, were analyzed by a single factor ANOVA after verification of the normality and the homoscedasticity of the data (R 3.3.3 software (Manufacturer by Kurt Hornik., Welthandelsplatz, Austria) [29]). Moreover, an HSD Tukey test of structuring of averages was carried out. 


\section{Results}

\subsection{PPP Used by the Surveyed Producers and Toxicity of Active Substances}

PPP and active substances used by producers are listed in Table 2. Eighteen (18) commercial formulations, consisting of $73 \%$ insecticides, $18 \%$ fungicides and $9 \%$ insecticides-acaricides, were identified. Five of these formulations are not approved by the Sahelian Pesticides Committee (SPC), which is the only office of the Permanent Inter-State Committee for Drought Control in the Sahel (CILSS) that regulates the use of pesticides in its Member States. The usage rate of pesticides registered for cotton but used on tomatoes was 54\% in Kouka and 25\% in Toussiana. Eleven active substances were identified; the most frequently used are $\lambda$-cyhalothrin (35\%), acetamiprid (22\%), profenofos (13\%) and cypermethrin (12\%). The most widely used chemical families are pyrethroids $(28 \%)$, organophosphates $(18 \%)$ and carbamates $(18 \%)$.

The calculation of the health risk index revealsed that methomyl, $\lambda$-cyhalothrin, profenofos and chlorothalonil are active substances that showed the highest risks of poisoning (Table 3). Both profenofos and indoxacarb present the highest risk of acute and chronic toxicity. 
Table 2. List of PPPs used by 30 producers in tomato production in Kouka and Toussiana (Burkina Faso).

\begin{tabular}{|c|c|c|c|c|c|c|}
\hline Trade Name of PPP & Area of Use & Formulation & Active Substances & Chemical Families & SPC Approval & WHO Class \\
\hline ACARIUS $018 \mathrm{EC}$ & Vegetables & EC & Abamectin $(18 \mathrm{~g} / \mathrm{L})$ & Avermectin & Yes & $\mathrm{I}$ \\
\hline AVAUNT $150 \mathrm{SC}$ & Cotton & CS & Indoxacarb $150 \mathrm{~g} / \mathrm{L}$ & Carbamates & Yes & - \\
\hline BIOK 16 & Vegetables & WP & Bt var. kurstaki: $2-4 \%(16,000 \mathrm{UI} / \mathrm{mg})$ & Bacillaceae & Yes & III \\
\hline COGA $80 \mathrm{WP}$ & Vegetables & WP & Mancozeb $(800 \mathrm{~g} / \mathrm{kg})$ & Carbamates & Yes & $\mathrm{U}$ \\
\hline CONQUEST $176 \mathrm{EC}$ & Cotton & $\mathrm{EC}$ & Cypermethrin $(144 \mathrm{~g} / \mathrm{L})+$ Acetamiprid $(32 \mathrm{~g} / \mathrm{L})$ & Pyrethroids + Neonicotinoids & Yes & II \\
\hline DUEL CP 186 EC & Cotton & EC & Cypermethrin (36 g/L) + Profenofos (150 g/L) & Pyrethroids + Organophosphates & None & II \\
\hline EMA 19.2 EC & Cotton & EC & Emamectin benzoate $(19.2 \mathrm{~g} / \mathrm{L})$ & Avermectin & Yes & II \\
\hline EMACOT 019 EC & Cotton & EC & Emamectin benzoate $(19 \mathrm{~g} / \mathrm{L})$ & Avermectin & Yes & II \\
\hline EMIR FORT 104 EC & Cotton & EC & Cypermethrin $(72 \mathrm{~g} / \mathrm{L})+$ Acetamiprid $(32 \mathrm{~g} / \mathrm{L})$ & Pyrethroids + Neonicotinoids & Yes & II \\
\hline JUMPER 75 WG & Vegetables & WG & Chlorothalonil $(750 \mathrm{~g} / \mathrm{kg})$ & Chloronitrile & Yes & $\mathrm{U}$ \\
\hline K-OPTIMAL & Vegetables & $\mathrm{EC}$ & $\lambda$-Cyhalothrin $(15 \mathrm{~g} / \mathrm{L})+$ Acetamiprid $(20 \mathrm{~g} / \mathrm{L})$ & Pyrethroids + Neonicotinoids & Yes & II \\
\hline LAMBDA POWER & Vegetables & EC & $\lambda$-Cyhalothrin $(25 \mathrm{~g})$ & Pyrethroids & None & II \\
\hline LAMBDA SUPER $2.5 \mathrm{EC}$ & Vegetables & EC & $\lambda$-Cyhalothrin $(25 \mathrm{~g})$ & Pyrethroids & None & II \\
\hline LAMBDACAL P636EC & Cotton & EC & $\Lambda$-Chyhalothrine $(36 \mathrm{~g} / \mathrm{L})+$ Profenofos $(600 \mathrm{~g} / \mathrm{L})$ & Pyrethroids + Organophosphates & Yes & II \\
\hline PACHA 25 EC & Vegetables & EC & $\Lambda$-Cyhalothrin $(15 \mathrm{~g} / \mathrm{L})+$ Acetamiprid $(10 \mathrm{~g} / \mathrm{L})$ & Pyrethroids + Neonicotinoids & Yes & II \\
\hline POLYTRINE 336 EC & Cotton & EC & Cypermethrin $(36 \mathrm{~g} / \mathrm{L})+$ Profenofos $(300 \mathrm{~g} / \mathrm{L})$ & Pyrethroids + Organophosphates & None & II \\
\hline SAVAHALER & Vegetables & WP & Methomyl $(250 \mathrm{~g} / \mathrm{kg})$ & Carbamates & Yes & $\mathrm{Ib}$ \\
\hline TROPISTAR 336 EC & Cotton & $\mathrm{EC}$ & Cypermethrin $(36 \mathrm{~g} / \mathrm{L})+$ Profenofos $(300 \mathrm{~g} / \mathrm{L})$ & Pyrethroids + Organophosphates & None & II \\
\hline
\end{tabular}

$\mathrm{EC}=$ Emulsifiable concentrate; $\mathrm{WP}=$ Wettable powder; $\mathrm{CS}=$ Concentrated suspension; WG = Water-dispersible granules; Class I: extremely/highly hazardous; Class Ib: very hazardous to humans; Class II: moderately hazardous; Class III: slightly hazardous, Class U: Unlikely to present a hazard to humans under normal use conditions. 
Table 3. Value of the parameters used in the calculation of the Health Risk Index (HRI) and the toxicity of the active substances used for tomato protection in Kouka and Toussiana (Burkina Faso).

\begin{tabular}{|c|c|c|c|c|c|c|c|c|c|}
\hline Active Substances & Use Rate & $\begin{array}{c}\Sigma \text { of Acute } \\
\text { Toxicity Points }\end{array}$ & $\begin{array}{c}\Sigma \text { of Chronic } \\
\text { Toxicity Points }\end{array}$ & FPer & TRI & $F P f$ & $F C P$ & $\begin{array}{c}\text { Points Allocated } \\
\text { to } H R I\end{array}$ & CLP Classification \\
\hline Profenofos & $12 \%$ & 20 & 18 & 1 & 1444 & 2 & 0.73 & 209.4 & H302, H312, H332 \\
\hline Indoxacarb & $6 \%$ & 15 & 18 & 1.5 & 1764 & 2 & 0.52 & 183.2 & Н301, H317, H332, H372 \\
\hline Methomyl & $2 \%$ & 26 & 4 & 1.5 & 1024 & 2 & 0.78 & 160.0 & $\mathrm{H} 300$ \\
\hline Mancozeb & $1 \%$ & 10 & 6 & 1 & 256 & 2 & 2.00 & 102.4 & H317, H361d \\
\hline Cypermethrin & $13 \%$ & 18 & 4 & 2 & 676 & 2 & 0.53 & 71.3 & H302, H332, H335 \\
\hline Chlorothalonil & $1 \%$ & 20 & 0 & 1 & 400 & 1 & 1.63 & 65.0 & H317, H318, H330, H335, H351 \\
\hline Abamectin & $4 \%$ & 19 & 4 & 1.5 & 625 & 2 & 0.51 & 64.2 & H300, H330, H361d, H372 \\
\hline$\lambda$-Cyhalothrin & $35 \%$ & 25 & 0 & 2 & 625 & 2 & 0.50 & 64.0 & H301, H312, H330 \\
\hline Emamectin benzoate & $5 \%$ & 17 & 0 & 1 & 289 & 2 & 0.51 & 29.3 & Unclassified \\
\hline Acetamiprid & $26 \%$ & 9 & 2 & 1 & 121 & 2 & 0.52 & 12.5 & H302 \\
\hline Bacillus thuringiensis & $1 \%$ & Unclassified & Unclassified & Unclassified & Unclassified & Unclassified & Unclassified & Unclassified & Unclassified \\
\hline
\end{tabular}

$F P e r=$ Factor taking into account the environmental persistence or the bioaccumulation potential in humans; TRI = Toxicological risk index of the active substance; $F P f=$ Weighting factor related to formulation type; $F C P=$ Compensation factor to account for the active substance concentration in the end-use product and the applied dose; $H R I=$ Health risk index for the active substance; H300 = Fatal if swallowed; H301 = Toxic if swallowed; H302 = Harmful if swallowed; H312 = Harmful in contact with skin; H317 = May cause an allergic skin reaction; H318 = Causes serious eye damage; H330 = Fatal if inhaled; H332 = Harmful if inhaled; H335 = May cause respiratory irritation; H351 = Suspected of causing cancer; H361d = Suspected of damaging fertility or the unborn child; H372 = Causes damage to organs through prolonged or repeated exposure 
The PPPs that pose the greatest risk to human health are: POLYTRINE 336 EC, TROPISTAR P 186 EC, AVAUNT 150 SC and LAMBDACAL P 636 EC (Table 4). These PPPs are normally recommended for cotton production.

Table 4. Decreasing ranking of the toxicity of pesticides used by tomato producers in Kouka and Toussiana (Burkina Faso) according to the Health Risk Index (HRI).

\begin{tabular}{ccc}
\hline Trade Name of PPP & Active Substances & Points Allocated to HRI \\
\hline POLYTRINE 336 EC & Cypermethrin + Profenofos & 280.63 \\
TROPISTAR P 186 EC & Cypermethrin + Profenofos & 280.63 \\
LAMBDACAL P 636 EC & Lambda-cyhalothrin + Profenofos & 273.29 \\
AVAUNT 150 SC & Indoxacarb & 183.15 \\
SAVAHALER & Methomyl & 160.00 \\
DUEL CP 186 EC & Cypermethrin + Profenofos & 136.05 \\
COGA 80 WP & Mancozeb & 102.40 \\
CONQUEST 176 EC & Acetamiprid + Cypermethrin & 83.71 \\
EMIR FORT & Acetamiprid + Cypermethrin & 83.71 \\
K-OPTIMAL & $\lambda$-Cyhalothrin + Acetamiprid & 76.37 \\
LAMANET 46 EC & $\lambda$-Cyhalothrin + Acetamiprid & 76.37 \\
PACHA 25 EC & $\lambda$-Cyhalothrin + Acetamiprid & 76.37 \\
JUMPER 75 WC & Chlorothalonil & 65.00 \\
ACARIUS 018 EC & Abamectin & 64.19 \\
LAMBDA POWER & $\lambda$-Cyhalothrin & 63.91 \\
LAMDA SUPER 2.5 EC & $\lambda$-Cyhalothrin & 63.91 \\
EMA 19.2 EC & Emamectin benzoate & 29.32 \\
EMACOT 019 EC & Emamectin benzoate & 29.32 \\
BIO K 16 & Bacillus thuringiensis & Unclassified \\
\hline
\end{tabular}

\subsection{Level of Education and PPE Worn by Tomato Producers}

Among the producers surveyed, $70 \%$ received no education and only $13 \%$ received training in plant protection. The lowest level of education was observed in the Township of Kouka ( $80 \%$ of surveyed producers). There were no PPE available in compliance with phytosanitary applications (mask, gloves, protective clothing) used by the surveyed producers (Table 5). The few producers who used masks and gloves, usually made of cloth, wore them during pesticide application only and not also during the preparation of the spray mix, despite the risk of inhaling concentrated pesticide vapors.

Table 5. Level of PPE adoption of 30 producers during the use of pesticides in tomato protection in Kouka and Toussiana (Burkina Faso).

\begin{tabular}{ccccc}
\hline PPE/Clothing & SS and S & SS and T & LS and T & Total \\
\hline No protection & $20 \%$ & $43 \%$ & $7 \%$ & $70 \%$ \\
Mask & $0 \%$ & $7 \%$ & $17 \%$ & $24 \%$ \\
Mask + Gloves & $0 \%$ & $3 \%$ & $3 \%$ & $6 \%$ \\
Total & $20 \%$ & $53 \%$ & $27 \%$ & $100 \%$ \\
\hline
\end{tabular}

$\mathrm{SS}=$ short sleeves; $\mathrm{S}=$ shorts LS = long sleeves; $\mathrm{T}=$ trousers.

\subsection{Status of Sprayers and PPP Dosage}

$30 \%$ of the backpack sprayers used by the producers surveyed are in poor condition and leak during pesticide application. Few producers (two from Kouka and five from Toussiana) meet the recommended dose of PPP. 27\% (three producers from Kouka and five from Toussiana) were below the recommended dose and 50\% of surveyed producers overdose their PPP (Figure 3). 


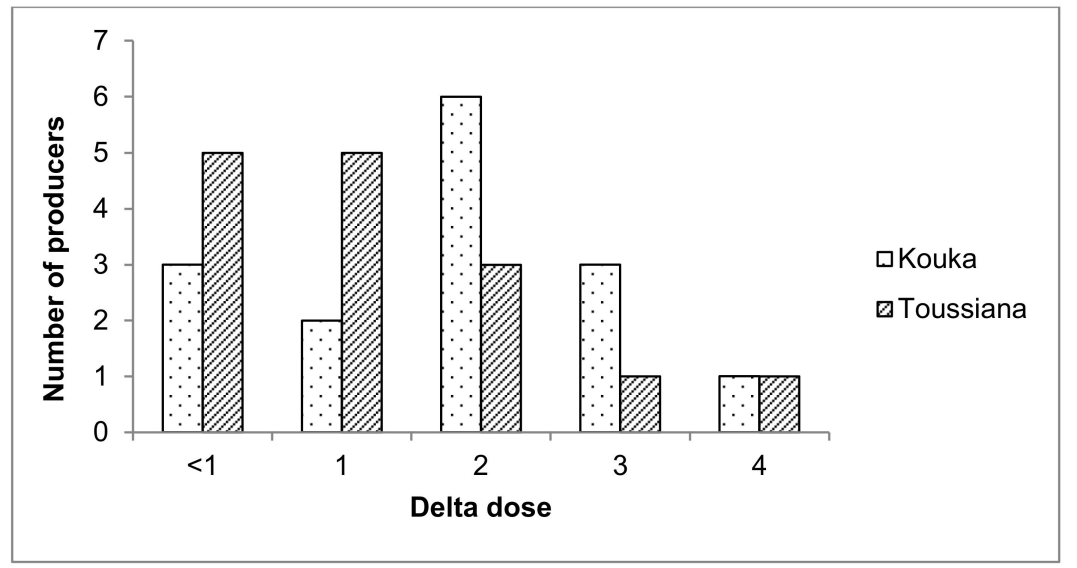

Figure 3. Pesticide dosage profile by the 30 tomato producers surveyed in Kouka and Toussiana (Burkina Faso). Delta dose is the ratio of the dose used by the producer ( $\mathrm{L}$ or $\mathrm{g}$ ) to the recommended dose for the treated area.

\subsection{Intensity of Treatment and Observed Carelessness}

The TFI indicates a high use of pesticides in the commune of Kouka, with nine producers above the 70th percentile compared to four producers in Toussiana (Table 6). Figure 4 shows a highly significant difference between sites $(p \leq 0.001)$. However within the same township, no significant difference was observed between the sites. The average number of treatments per tomatoes production cycle is $11.93 \pm 2.58$ in Kouka and $5.33 \pm 1.68$ in Toussiana.

Table 6. TFI values for tomato protection in Kouka and Toussiana (Burkina Faso).

\begin{tabular}{cccccc}
\hline Communes & Number of Producers & TFI Minimum & Average TFI & TFI at the 70th Percentile & Maximum TFI \\
\hline Kouka & 15 & 0.36 & $2.29 \pm 2.24$ & 2.32 & 9.78 \\
Toussiana & 15 & 0.03 & $0.27 \pm 0.20$ & 0.30 & 0.83 \\
Total & 30 & 0.03 & $1.28 \pm 1.87$ & 1.67 & 9.78 \\
\hline
\end{tabular}

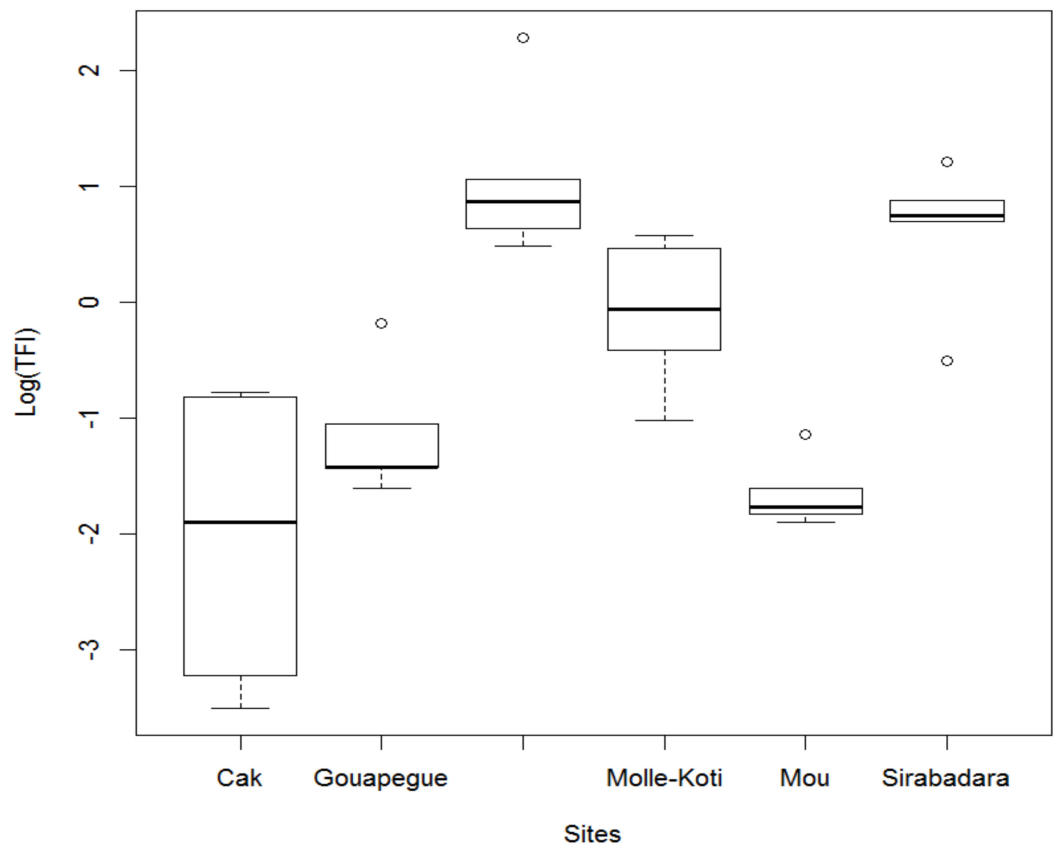

Figure 4. Comparison of TFI of the six sites observed in the communes of Kouka and Toussiana (Burkina Faso). 
As for the carelessness observed which may favor the rapid exposure of the operator to pesticides, they are represented in Figure 5. All market gardeners surveyed used their bare hands to manipulate the product packaging and contaminated objects (measuring instruments, lance, nozzles) and $43 \%$ did not wash their hands before urinating during the application of PPP.

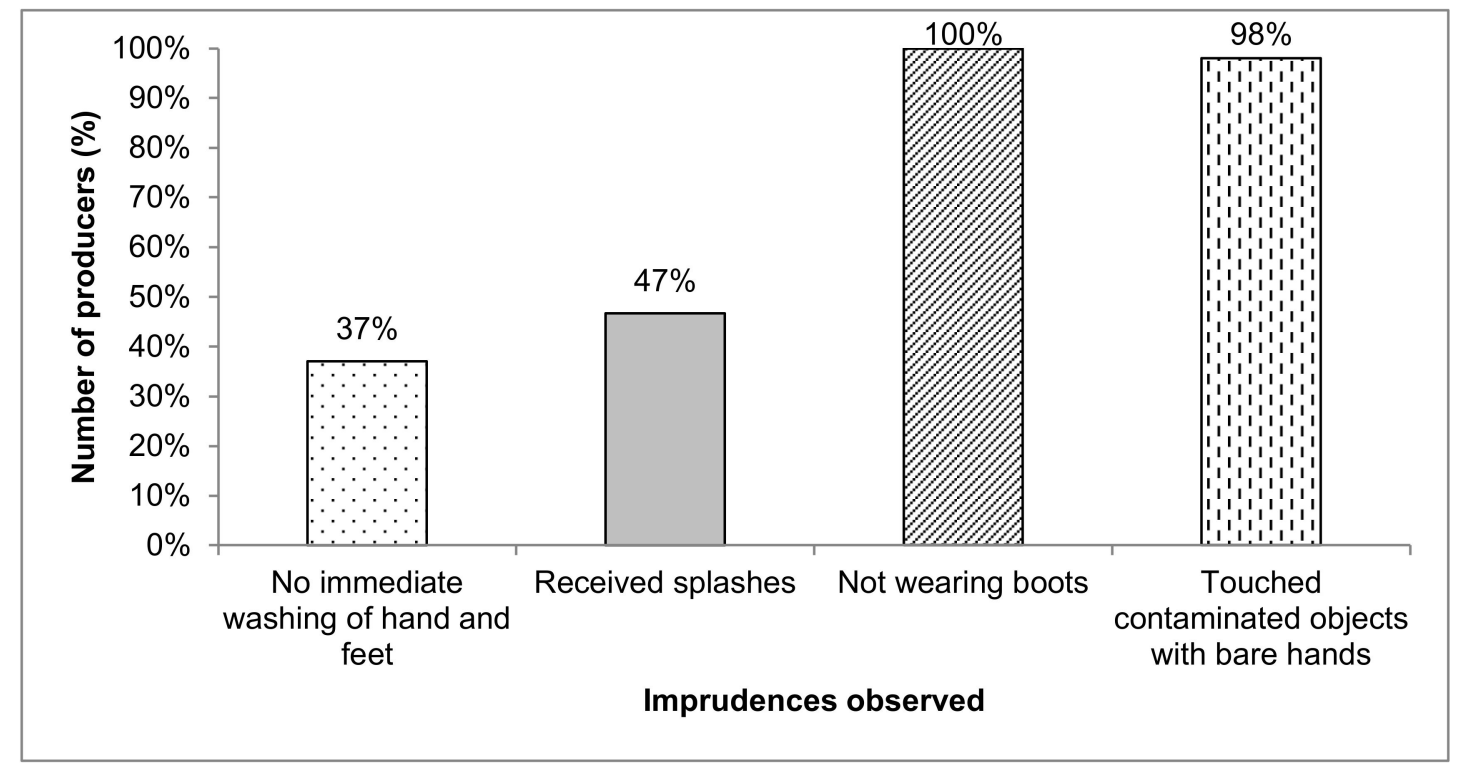

Figure 5. Types of carelessness observed during treatments amongst 30 producers in Kouka and Toussiana (Burkina Faso).

\subsection{Exposure Risks and Health Effects Witnessed by Producers.}

Results in Table 7 show that producers could be highly exposed to pesticides, especially in Kouka Township. Apart from cypermethrin and acetamiprid, all used active substances presented unacceptable risks to the operator with estimated exposure levels exceeding several times the acceptable operator exposure level (AOEL). The potential values for dermal exposure during mixing, loading and spraying when producers work without PPE range from $0.0136 \mathrm{mg} / \mathrm{kg} \mathrm{bw} /$ day (acetamiprid) to $1.7855 \mathrm{mg} / \mathrm{kg}$ bw / day (chlorothalonil) in Kouka and from $0.0105 \mathrm{mg} / \mathrm{kg} \cdot \mathrm{bw} /$ day (acetamiprid) to $0.2914 \mathrm{mg} / \mathrm{kg}$ bw/day (profenofos) in Toussiana. $\lambda$-Cyhalothrin is more likely to be exposed at more than $2000 \%$ of AOEL in both townships. However, when using complete PPE (wearing of mask, gloves and protective clothing), the risk of exposure is reduced by more than 800 times with $\lambda$-cyhalothrin. In terms of the effects felt by producers during or after pesticide use, $57 \%$ of producers reported that they felt certain health effects such as skin irritation ( $23 \%)$, eye diseases $(19 \%)$, nasal discharge and coughing (11\%). 
Table 7. Decreasing ranking of the exposure of tomato producers in Kouka and Toussiana (Burkina Faso).

\begin{tabular}{|c|c|c|c|c|c|c|c|c|c|c|c|c|}
\hline \multirow[t]{2}{*}{ Active Substances } & \multirow[t]{2}{*}{$\begin{array}{l}\mathrm{LD}_{50}(\text { Dermal) } \\
\text { (mg/kg·bw/day) }\end{array}$} & \multicolumn{2}{|c|}{$\begin{array}{l}\text { Number of Producers } \\
\text { Using This Active } \\
\text { Substance }\end{array}$} & \multicolumn{2}{|c|}{$\begin{array}{c}\text { Operator Exposure } \\
\text { (mg/kg.bw/day): } \\
\text { Unprotected }\end{array}$} & \multicolumn{2}{|c|}{$\begin{array}{l}\text { Operator Exposure } \\
\text { (mg/kg.bw/day): } \\
\text { Complete Protection }\end{array}$} & \multirow[t]{2}{*}{$\begin{array}{c}\text { AOEL } \\
(\mathrm{mg} / \mathrm{kg} \cdot \mathrm{bw} / \text { day })\end{array}$} & \multicolumn{2}{|c|}{$\begin{array}{c}\% \text { AOEL } \\
\text { (Unprotected) }\end{array}$} & \multicolumn{2}{|c|}{$\begin{array}{l}\text { \% AOEL (Complete } \\
\text { Protection) }\end{array}$} \\
\hline & & Kouka & Toussiana & Kouka & Toussiana & Kouka & Toussiana & & Kouka & Toussiana & Kouka & Toussiana \\
\hline Chlorothalonil & $>10,000$ & 1 & 0 & 1.7855 & - & 0.3978 & - & 0.0090 & $19,839 \%$ & - & $4420 \%$ & - \\
\hline Methomyl & $>2000$ & 0 & 2 & - & 0.1738 & - & 0.0204 & 0.0025 & - & $6950 \%$ & - & $816 \%$ \\
\hline Mancozeb & $>5000$ & 1 & 0 & 1.6905 & - & 0.2371 & - & 0.035 & $4830 \%$ & - & $677 \%$ & - \\
\hline Emamectin benzoate & $>2000$ & 2 & 2 & 0.0129 & 0.0144 & 0.0018 & 0.0018 & 0.0003 & $4314 \%$ & $4800 \%$ & $611 \%$ & $583 \%$ \\
\hline Lamda-cyhalothrin & 632 & 14 & 12 & 0.0172 & 0.0151 & 0.0021 & 0.0021 & 0.0006 & $2732 \%$ & $2410 \%$ & $339 \%$ & $339 \%$ \\
\hline Indoxacarb & $>5000$ & 5 & 0 & 0.0714 & - & 0.0080 & - & 0.0040 & $1785 \%$ & - & $199 \%$ & - \\
\hline Profenofos & $>2000$ & 9 & 1 & 0.2753 & 0.2914 & 0.0319 & 0.0442 & Unavailable & - & - & - & - \\
\hline Abamectine & $>2000$ & 0 & 3 & - & 0.0151 & - & 0.0021 & 0.0025 & - & $604 \%$ & - & $83 \%$ \\
\hline Cypermethrin & $>4920$ & 9 & 2 & 0.0595 & 0.0407 & 0.0065 & 0.0058 & 0.0600 & $99 \%$ & $68 \%$ & $11 \%$ & $10 \%$ \\
\hline Acetamiprid & $>2000$ & 10 & 12 & 0.0136 & 0.0105 & 0.0016 & 0.0015 & 0.0700 & $19 \%$ & $15 \%$ & $2 \%$ & $2 \%$ \\
\hline
\end{tabular}

The $\mathrm{LD}_{50}$ is the amount of a single-dose administered at one time that causes the death of $50 \%$ (half) of a group of test animals. 


\section{Discussion}

The results show a high use of PPP normally recommended for cotton production being used tomatoes, especially in the Kouka township, and that they present a high risk to health according to the calculated HRI. Schiffers and Mar [8] reported that these PPP are not recommended in vegetable production because of their high toxicity and high concentration of active substances. Pyrethrinoids are the most commonly used, and several authors have reported the resistance of the main tomato pests like B. tabaci, H. armigera and T. absoluta to the insecticides of this chemical family [30-32]. This choice leads to an intensification of treatments and consequently to an increased risk of poisoning from exposure. Among the formulations used, $75 \%$ are liquid. In general, the substances present in these formulations are more easily absorbed through the skin and other tissues than solid formulations [33]. According to Berenstein et al. [34], exposure from liquid PPP is 22 to 62 times higher than that of solid PPP.

While the use of PPP requires a minimum amount of knowledge to work safely, the results of the study showed a low level of education and training of the producers. Unable to read or write, producers' capability to understand and follow instructions mentioned on the labels (dose to be applied, safety instructions, PPE to be worn, hygiene, etc.) is limited, which increases the risks of exposure. According to Jallow et al. [35], insufficient knowledge, the influence of retailers, and the lack of access to alternative pest management methods are pushing producers to use PPP. On the other hand, the higher the level of education and training, the lower the exposure $[35,36]$. Therefore, after two years of Integrated Pest Management (IPM) training, [37] found that trained farmers used less pesticide, spent less money on pest management, and endured less exposure to pesticides. In Mali, after 8 years of IPM training, the use of hazardous insecticides by cotton producers decreased by $92.5 \%$ compared to those who had not received training [38].

Compliance with the type of PPE depending on the toxicity of the pesticide used, the formulation (liquid, powder or granules) and the type of activity (mixing, loading or spraying), enables the pesticide applicator to reduce exposure. A study conducted in lemon trees revealed that dermal exposure would be reduced by $27 \%$ by using gloves, $38 \%$ by protective clothing and $65 \%$ by gloves and protective clothing [39].

However, our study showed a low level (or absence) of producer protection. The few producers who used masks and gloves wore them during the application of pesticides but not during the preparation of the mixture when the greatest exposure occurs because the product is handled in the concentrated state and the risk of inhalation of concentrated pesticide vapors remains high $[8,40,41]$. $64 \%$ of hand contamination occurred during the mixing-loading phases [36], 20\% of producers' wore short-sleeved clothing and shorts, while several studies have highlighted heavy contamination of legs and forearms during pesticide application [36,42-44]. Another factor favoring producers' exposure to pesticides is the use of defective sprayers that leaked during the application of pesticides. This increases the contamination rate, because even in the normal state (absence of leaks), contamination via the hands is $25 \%$ and $50 \%$ by the legs with the backpacker if there is no adequate protection [45].

In addition to the lack of wearing of PPE and the use of defective sprayers, the intensification of treatments (increased doses and number of treatments) also favors the exposure of producers to pesticides. According to several authors [46], dermal and respiratory exposure is proportional to the application rate and the frequency of application. According to Baldi et al. [47] spraying is responsible for $50 \%$ of the total daily exposure. Failure to comply with hygienic measures such as washing hands before urinating during PPP application is also a very important risk factor for pesticide contamination of producers. In accordance with Poet [48], pesticides are absorbed 12 times faster by the genitals compared to the forearms.

The weather conditions at the time of application, such as temperature and air humidity, can affect the volatility of the product and the rate of sweating of human body $[46,49,50]$. High temperatures cause excessive sweating to promote rapid penetration of the product into the body and winds above normal $(1$ and $2 \mathrm{~m} / \mathrm{s})$ can transport the product out of the targeted zone and cause contamination of the 
applicator by the pesticide $[46,51,52]$. The meteorological conditions recorded at the level of the two localities during the application of pesticides are within the recommended ranges in the exposure of the operators. Pesticide applications are carried out either very early in the morning or in the evening when the weather conditions are favorable.

$\lambda$-Cyhalothrin presents an unacceptable risk of toxicity to producers, where it is most used in market gardening production in Burkina Faso and in the subregion $[9,12,27,53,54]$. This active substance is extremely toxic to humans (irritation of eyes, skin, colds and coughs) [55,56]. This could largely explain the malaise felt by $57 \%$ of the producers monitored. In the short term, it is neurotoxic (ataxia, tremors, occasional convulsions), but in the long term it is not carcinogenic or genotoxic and has no effect on reproduction and development but rather causes a decrease in body weight [55]. However, with mask, gloves and protective clothing, the risk of exposure can be reduced by more than 800 times, thus demonstrating the importance for the operator to wear complete PPE to reduce pesticide contamination $[7,57,58]$.

\section{Conclusions}

The results of this study showed an intensification of pesticide use in tomato production in Burkina Faso with high exposure risks. According to the study, there is little training of producers in the use of plant protection products in relation to their inappropriate practices (use of highly toxic pesticides, overdose, no use of PPE, etc.). Apart from acetamiprid and cypermethrin, all the active substances exceeded the exposure values of their acceptable exposure level (AOEL) for the operator. $\lambda$-Cyhalothrin, which is the most widely used active ingredient in vegetable production in Burkina Faso, and in the two localities studied, present a particularly high risk of exposure for the producers. However, this exposure can be reduced by 800 times if recommended PPE were used. To promote the rational management of pesticides and limit their impact on human health and the environment in Burkina Faso, it is necessary to reduce and control the use of pesticides by:

- $\quad$ Raising awareness among producers to the risks and the training on the recognition of pests and auxiliaries to be respected;

- Increasing popularity of biopesticides and alternative methods, as well as the promotion of integrated pest management;

- $\quad$ Providing training based on the rules of best practice for the use of pesticides, emphasizing safety instructions and the importance of the use of protective equipment.

Acknowledgments: This study was carried out with the financial support of the ARES-CDD (PIC Project "Integrated Management of Phytosanitary Problems in Burkina Faso", UCL-ULg-IDR/UPB).

Author Contributions: This research was undertaken as part of Diakalia Son's Doctor of Phytopharmacy thesis. Bruno Schiffers is the promoter of this thesis. Diakalia Son, Fabrice K. B. Zerbo, Schémaeza Bonzi, Anne Legreve, Irénée Somda and Bruno Schiffers contributed significantly to the successful completion of this research work both intellectually and financially. Accordingly, they conceived and designed the study plan. Diakalia Son conducted sampling, analyzed the data, and wrote the initial manuscript. Bruno Schiffers guided this study and provided revisions on the manuscript. Finally, all the authors have read and approved the final manuscript.

Conflicts of Interest: The authors declare no conflict of interest.

\section{References}

1. Ministère de l'Agriculture, des Ressources Halieutiques, de l'Assainissement et de la Sécurité Alimentaire (MARHASA) du Burkina Faso. Superficies et Production Maraîchère par Région (Campagne 2013-2014); Ministère de l'Agriculture, des Ressources Halieutiques, de l'Assainissement et de la Sécurité Alimentaire (MARHASA): Ouagadougou, Burkina Faso, 2014; 5p.

2. Konaté, G.; Barro, N.; Fargette, D.; Swanson, M.M.; Harrison, B.D. Occurrence of whitefly-transmitted geminiviruses in crops in Burkina Faso, and their serological detection and differentiation. Ann. Appl. Biol. 1995, 126, 121-130. [CrossRef] 
3. Ouattara, A.; Tiendrébéogo, F.; Lefeuvre, P.; Claverie, S.; Hoareau, M.; Traoré, E.V.; Barro, N.; Traoré, O.; Lett, J.-M. Tomato leaf curl Burkina Faso virus: A novel tomato-infecting monopartite begomovirus from Burkina Faso. Arch. Virol. 2017, 162, 1427-1429. [CrossRef] [PubMed]

4. Son, D.; Bonzi, S.; Somda, I.; Bawin, T.; Boukraa, S.; Verheggen, F.; Francis, F.; Legreve, A.; Schiffers, B. First record of Tuta Absoluta (Meyrick, 1917) (Lepidoptera: Gelechiidae) in Burkina Faso. Afr. Entomol. 2017, 25, 259-263. [CrossRef]

5. Alavanja, M.C.R.; Hoppin, J.A.; Kamel, F. Health effects of chronic pesticide exposure: Cancer and neurotoxicity. Annu. Rev. Public Health 2004, 25, 155-197. [CrossRef] [PubMed]

6. Tomenson, J.A.; Matthews, G.A. Causes and types of health effects during the use of crop protection chemicals: Data from a survey of over 6300 smallholder applicators in 24 different countries. Int. Arch. Occup. Environ. Health 2009, 82, 935-949. [CrossRef] [PubMed]

7. Ouédraogo, R.; Toé, A.M.; Ilboudo, S.; Guissou, P.I. Risk of workers exposure to pesticides during mixing/loading and supervision of the application in sugarcane cultivation in Burkina Faso. Int. J. Environ. Sci. Toxicol. Res. 2014, 2, 143-151.

8. Schiffers, B.; Mar, A. Sécurité des Opérateurs et Bonnes Pratiques Phytosanitaires; COLEACP/PIP Press: Brussels, Belgium, 2011; 246p.

9. Son, D.; Somda, I.; Legreve, A.; Schiffers, B. Pratiques phytosanitaires des producteurs de tomates du Burkina Faso et risques pour la santé et l'environnement. Cah. Agric. 2017. [CrossRef]

10. Macfarlane, E.; Carey, R.; Keegel, T.; El-Zaemay, S.; Fritschi, L. Dermal exposure associated with occupational end use of pesticides and the role of protective measures. Saf. Health Work 2013, 4, 136-141. [CrossRef] [PubMed]

11. Ouédraogo, M.; Tankoana, A.; Ouédraogo, T.Z.; Guissou, I.P. Étude des facteurs de risques d'intoxication chez les utilisateurs de pesticides dans la région cotonnière de Fada N'Gourma au Burkina Faso. Environ. Risques Santé 2009, 8, 343-347.

12. Ahouangninou, C.; Fayomi, B.E.; Martin, T. Evaluation des risques sanitaires et environnementaux des pratiques phytosanitaires des producteurs maraîchers dans la commune rurale de Tori-Bossito (Sud-Bénin). Cah. Agric. 2011, 20, 216-222.

13. Tarla, D.N.; Meutchieye, F.; Assako, V.A.; Fontem, D.A.; Kome, J.J.A. Exposure of market gardeners during pesticide application in the western highlands of Cameroon. Sch. J. Agric. Sci. 2013, 3, 172-177.

14. Kamel, F.; Hoppin, J.A. Association of pesticide exposure with neurologic dysfunction and disease. Environ. Health Perspect. 2004, 112, 950-958. [CrossRef] [PubMed]

15. Fernandes, F.L.; Bacci, L.; Fernandes, M.S. Impact and selectivity of insecticides to predators and parasitoids. EntomoBrasilis 2010, 3, 1-10. [CrossRef]

16. Agbohessi, T.P.; Toko, I.I.; Kestemont, P. État des lieux de la contamination des écosystèmes aquatiques par les pesticides organochlorés dans le Bassin cotonnier béninois. Cah. Agric. 2012, 21, 46-56.

17. Comité Permanet Inter-États de Lutte Contre la Sécheresse dans le Sahel (CILSS). Réglementation Commune aux états Membres du CILSS sur L'homologation des Pesticides; CILSS: Ouagadougou, Burkina Faso, 1999; 30p.

18. European Food Safety Authority (EFSA). Guidance on the assessment of exposure of operators, workers, residents and bystanders in risk assessment for plant protection products. EFSA J. 2014, 12, 55.

19. Samuel, O.; Dion, S.; St-Laurent, L.; April, M.H. Indicateur de Risque des Pesticides du Québec-IROeQ-Santé et Environnement; Ministère de l'Agriculture, des Pêcheries et de l'Alimentation/Ministère du Développement Durable, de l’Environnement et des Parcs/Institut National de santé Publique du Québec: Quebec, QC, Canada, 2012; 48p.

20. EU-Pesticides Database. Available online: http://ec.europa.eu/food/plant/pesticides/eu-pesticides-database/ public/?event=activesubstance.detail\&language=EN\&selectedID=1755 (accessed on 12 November 2017).

21. Ahouangninou, C.; Martin, T.; Edorh, P.; Bio-Bangana, S.; Samuel, O.; St-Laurent, L.; Dion, S.; Fayomi, B. Characterization of health and environmental risks of pesticide use in market-gardening in the rural city of Tori-Bossito in Benin, West Africa. J. Environ. Prot. 2012, 3, 241-248. [CrossRef]

22. Bouagga, A.; Chaabane, H.; Bahrouni, H.; Hassine, K. The use of IRPeQModel as indicator to estimate the risk of some pesticides on human health and environment. Tunis. J. Plant Prot. 2016, 11, 133-141.

23. Pingault, N.; Pleyber, E.; Champeaux, C.; Guichard, L.; Omon, B. Produits phytosanitaires et protection intégrée des cultures: L'indicateur de fréquence de traitement (IFT). Notes et Études Socio-Économiques 2009, $32,61-94$. 
24. Ministère de l'Agriculture, de l'Agroalimentaire et de la Forêt (MAAF). Guide Méthodologique. Indicateur de Fréquence de Traitements Phytopharmaceutiques (IFT); MAAF: Paris, France, 2015; 58p.

25. Direction Régionale de l'Alimentation, de l'Agriculture et de la Forêt (DRAAF). La Methodologie de Calcul de L'indicateur de Frequence de Traitements (IFT); DRAAF: Auvergne-Rhône-Alpes, France, 2014; 4p.

26. Kim, S.-H.; Lee, C.-H.; Kim, K.-H.; Jeong, S.-H. Comparative estimation of exposure level and health risk assessment of highly produced pesticides to agriculture operators by using default dermal absorption rate or actual measurement values. Biomed. Sci. Lett. 2016, 22, 199-206. [CrossRef]

27. Illyassou, K.M.; Adamou, R.; Schiffers, B. Risk assessment for small farmers exposed to plant protection products in the Niger river valley. Commun. Appl. Biol. Sci. 2017, 81, 1-13.

28. World Health Organization (WHO). Generic Risk Assessment Model for Indoor and Outdoor Space Spraying of Insecticides; WHO: Geneva, Switzerland, 2011.

29. A Language and Environment for Statistical Computing. R Foundation for Statistical. Computing. 2017. Available online: https:/ / www.r-project.org/ (accessed on 15 June 2017).

30. Siqueira, H.A.A.; Guedes, R.N.C.; Picanco, M.C. Insecticide resistance in populations of Tuta absoluta (Lepidoptera: Gelechiidae). Agric. For. Entomol. 2000, 2, 147-153. [CrossRef]

31. Achaleke, J.; Brévault, T. Inheritance and stability of pyrethroid resistance in the cotton bollworm Helicoverpa armigera (Lepidoptera: Noctuidae) in Central Africa. Pest Manag. Sci. 2009, 66, 137-141.

32. Gnankiné, O.; Mouton, L.; Savadogo, A.; Martin, T.; Sanon, A.; Dabire, R.K.; Vavre, F.; Fleury, F. Biotype status and resistance to neonicotinoids and carbosulfan in Bemisia tabaci (Hemiptera: Aleyrodidae) in Burkina Faso, West Africa. Int. J. Pest Manag. 2013, 59, 95-102. [CrossRef]

33. Kim, K.-H.; Kabir, E.; Jahan, S.A. Exposure to pesticides and the associated human health effects. Sci. Total Environ. 2017, 575, 525-535. [CrossRef] [PubMed]

34. Berenstein, G.A.; Hughes, E.A.; March, H.; Rojic, G.; Zalts, A.; Montserrat, J.M. Pesticide potential dermal exposure during the manipulation of concentrated mixtures at small horticultural and floricultural production units in Argentina: The formulation effect. Sci. Total Environ. 2014, 472, 509-516. [CrossRef] [PubMed]

35. Jallow, M.F.A.; Awadh, D.G.; Albaho, M.S.; Devi, V.Y.; Thomas, B.M. Pesticide risk behaviors and factors influencing pesticide use among farmers in Kuwait. Sci. Total Environ. 2017, 574, 490-498. [CrossRef] [PubMed]

36. Lebailly, P.; Bouchart, V.; Baldi, I.; Lecluse, Y.; Heutte, N.; Gislard, A.; Malas, J.-P. Exposure to pesticides in open-field farming in France-Abstract. Ann. Occup. Hyg. 2009, 53, 69-81. [PubMed]

37. Hruska, A.J.; Corriols, M. The impact of training in integrated pest management among nicaraguan maize farmers: Increased net returns and reduced health risk. Int. J. Occup. Environ. Health 2002, 8, 191-200. [CrossRef] [PubMed]

38. Settle, W.; Soumare, M.; Sarr, M.; Garba, M.H.; Poisot, A.-S. Reducing pesticide risks to farming communities: Cotton farmer field schools in Mali. Philos. Trans. R. Soc. B Biol. Sci. 2014. [CrossRef] [PubMed]

39. Nigg, H.N.; Stamper, J.H.; Queen, R.M. Dicofol exposure to Florida citrus applicators: Effects of protective clothing. Arch. Environ. Contam. Toxicol. 1986, 15, 121-134. [CrossRef] [PubMed]

40. Flores, A.P.; Berenstein, G.A.; Hughes, E.A.; Zalts, A.; Montserrat, J.M. Pesticide risk assessment in flower greenhouses in Argentina: The importance of manipulating concentrated products. J. Hazard. Mater. 2011, 189, 222-228. [CrossRef] [PubMed]

41. Lawson, A.J.; Akohou, H.; Lorge, S.; Schiffers, B. Three methods to assess levels of farmers' exposure to pesticides in the urban and peri-urban areas of Northern Benin. Tunis. J. Plant Prot. 2017, 12, 91-108.

42. Syamimi, I.; Tengku Hanidza, T.I.; Puziah, A.L. Estimation of the pesticide exposure during spraying among applicators. Health Environ. J. 2011, 2, 18-22.

43. Kim, E.; Moon, J.-K.; Lee, H.; Kim, S.; Hwang, Y.-J.; Kim, B.-J.; Lee, J.; Lee, D.-H.; Kim, J.-H. Exposure and risk assessment of operators to insecticide acetamiprid during treatment on apple orchard. Korean J. Hort. Sci. Technol. 2013, 31, 239-245. [CrossRef]

44. Kim, E.; Moon, J.-K.; Choi, H.; Kim, J.-H. Probabilistic exposure assessment for applicators during treatment of the fungicide kresoxim-methyl on an apple orchard by a speed sprayer. J. Agric. Food Chem. 2015, 63, 10366-10371. [CrossRef] [PubMed]

45. Agence Nationale de Sécurité Sanitaire de L'alimentation, de L'environnement et du Travail (ANSES). Exposition aux Pesticides; ANSES: Maisons-Alfort, France, 2010; 52p. 
46. Fenske, R.A.; Day, E.W. Assessment of exposure for pesticide handlers in agricultural, residential and institutional environments. In Occupational and Residential Exposure Assessment for Pesticides; John Wiley \& Sons, Ltd.: Hoboken, NJ, USA, 2005; pp. 11-43.

47. Baldi, I.; Lebailly, P.; Bouvier, G.; Rondeau, V.; Kientz-Bouchart, V.; Canal-Raffin, M.; Garrigou, A. Levels and determinants of pesticide exposure in re-entry workers in vineyards: Results of the PESTEXPO study. J. Expo. Sci. Environ. Epidemiol. 2012, 22, 593-600. [CrossRef] [PubMed]

48. Poet, T.S. Assessing dermal absorption. Toxicol. Sci. 2000, 58, 1-2. [CrossRef] [PubMed]

49. Aubertot, J.N.; Barbier, J.M.; Carpentier, A.; Gril, J.J.; Guichard, L.; Lucas, P.; Savary, S.; Savini, I.V.M. Agriculture et environnement. In Réduire L'utilisation des Pesticides et en Limiter les Impacts Environnementaux Expertise Scientifique Collective, Synthèse du Rapport; INRA et Cemagref: Paris, France, 2005; 64p.

50. Gil, Y.; Sinfort, C.; Guillaume, S.; Brunet, Y.; Palagos, B. Influence of micrometeorological factors on pesticide loss to the air during vine spraying: Data analysis with statistical and fuzzy inference models. Biosyst. Eng. 2008, 100, 184-197. [CrossRef]

51. Schiffers, B.; Moreira, C. Fondements de la Protection des Cultures; COLEACP/PIP Press: Brussels, Belgium, 2011; 294p.

52. El-Aissaoui, A. Guide Pratique pour les Opérateurs Agricoles: Les Bases de L'application Rationnelle des Produits Phytosanitaires; INRA: Settat, Maroc, 2015; 32p.

53. Ohui, D.H. Risques Environnementaux et Sanitaires Associés à L'utilisation des Pesticides Autour de Petites Retenues d'eau: Cas du Bassin Versant de Nariarlé; En Ingénierie de l'eau et de L'environnement: Ouagadougou, Burkina Faso, 2014; 110p.

54. Lehmann, E.; Dibié, J.-J.N.; Konaté, Y.; de Alencastro, L.P. Pesticides use in gardening areas in Burkina Faso and evaluation of the resulting risk for the operator using the new AOEM proposed by EFSA guidelines. In Proceedings of the 68th International Symposium on Crop Protection, Ghent, Belgique, 17 May 2016.

55. Joint Meeting on Pesticide Residues (JMPR). Lambda-Cyhalothrin; Federal Institute for Risk Assessment: Berlin, Germany, 2007; pp. 549-783.

56. Institut National de l'Environnement Industriel et des Risques (INERIS). Fiche de la Lambda Cyhalothine-N ${ }^{\circ}$ CAS 91465-08-6; Validation du Groupe D'experts de Juin 2011; INERIS: Paris, France, 2011; 18p.

57. Toé, A.M.; Ouedraogo, M.; Ouedraogo, R.; Ilboudo, S.; Guissou, P.I. Pilot study on agricultural pesticide poisoning in Burkina Faso. Interdiscip. Toxicol. 2013, 6, 185-191. [CrossRef] [PubMed]

58. Wumbei, A. Risk assessment of applicator exposure to pesticides on cotton farms in Ghana. J. Environ. Earth Sci. 2013, 3, 156-172. 